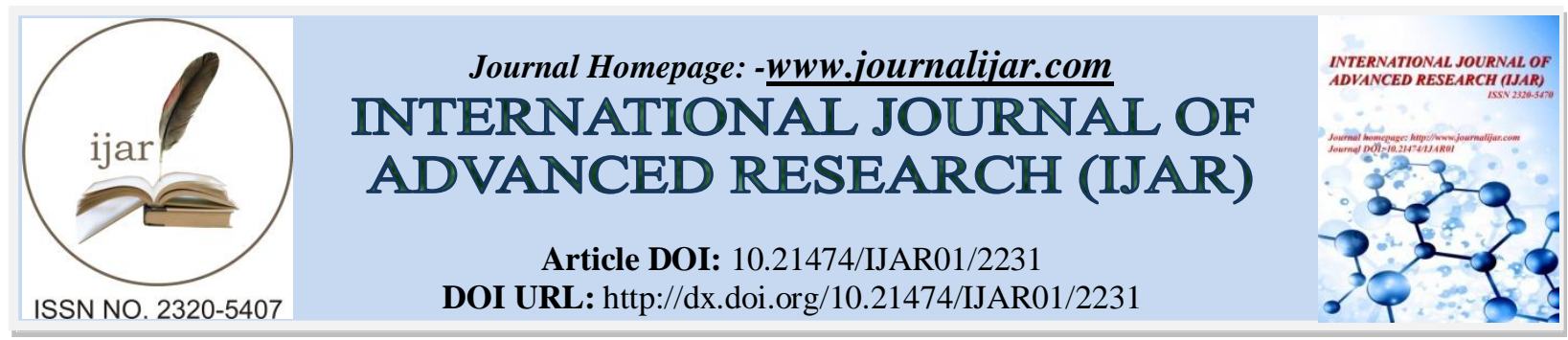

RESEARCH ARTICLE

\title{
A STUDY ON PROBLEM AND PROSPECTS OF WOMEN ENTREPRENEURS WITH SPECIAL REFERENCE TO GUNTUR DISTRICT, ANDHRA PRADESH.
}

Dr. Poorna Prabhat Sunkara.

Assistant Professor,Department of MBA,Andhra Loyola College, Vijayawada.

\section{Manuscript Info}

Manuscript History

Received: 28 September 2016

Final Accepted: 30 October 2016

Published: November 2016

Key words:-

Women Empowerment, Socio-

Economic, Women

Entrepreneur,problems andprospects

\begin{abstract}
Today, women entrepreneurs play a vital role in the overall economic development of the country. Women have been successful coming out of their homes by entering into different kinds of business and services. Women entrepreneurs have proved that they are equally doing business with the men and are emerging as dynamic entrepreneurs. They are accepting the challenging role to meet her personal needs and become economically independent. The Andhra Pradesh state is a newly formed capital, where there will be plenty of resources available. Moreover, the government is creating awareness consequently also organizes different programmes for encouraging women by various associations, but they are not ready to undertake the business. Women are less encouraged to start business units due to the various issues like financial problems, lack of motivation, and support from their family members. Hence, the study aims at Importance of entrepreneurial development among women and also to analyze the socio-economic framework, problems and prospects of women entrepreneurs in Guntur District, Andhra Pradesh. A sample size of 90respondents was surveyed by using a structured questionnaire for the study. The research clearly mentioned the factors affecting them based on the opinions of respondents.
\end{abstract}

Copy Right, IJAR, 2016,. All rights reserved.

\section{Introduction:-}

The development of women entrepreneurship enables society to understand and appreciate their abilities in doing business. It gives them social status and they can build up their confidence levels, consequently which gives them psychological satisfaction. It leads to the integration of the nation. Therefore, which facadeina sense of achievement. Divers of the Entrepreneurship Development Program were conducted by different organizations for women to create entrepreneurial awareness among them.

These women leaders are willing to take any type of challenges and risks. They managed to survive and succeed in this massive competitive world with their solid work, diligence, ability to learn quickly and to motivate people, knowing how to win and lose gracefully are the strengths of the Indian women entrepreneurs.

Entrepreneurship is a rapidly rising concern of a modern competitive economy and its contribution in an economy is viably recognized worldwide. India is a developing country is still on its way to understand the need of selfemployed. When compared to last decade the idea of self-employment has really increased up and various Small and

Corresponding Author: -Dr.Poorna Prabhat Sunkara.

Address: -Assistant Professor,Department of MBA,Andhra Loyola College, Vijayawada. 
Medium scale Industries have emerged in India and contributing to its economic growth \& development, especially women entrepreneurs has been increased. This process of development requires equal participation of all citizens.

\section{Women Entrepreneur in India:-}

Women constitute majority of $50 \%$ of the total population of India, if they provided with the proper training, education, and motivation can play a vital role in the growth of the overall economy of India. According to Study done by BNP Paribas in 2015 showed that India had the maximum number of women entrepreneurs in percentage terms at $49 \%$. Women entrepreneurs in the country choose traditional businesses like Beauty parlors, bakeries, handicrafts, boutiques, interior designing, and Textiles etc. They are in key positions like chamber of commerce members. The following are the major circumstances influencing the women entrepreneur.

Socio-Economic factors

Motivational factors

Family responsibilities and commitments

Awareness about the financial aid

Exposed to the different training programs

Identifying the available resources

Lack of Education and Illiteracy

Establishing their own identity in the society

Building self-confidence.

Developing risk-taking ability

\section{Objectives of the study:-}

To study the socio- economic factors of the women entrepreneurs in Guntur District,

Andhra Pradesh

To analyze the problems of women entrepreneurs in setting up and running their Business

To provide solutions to improve the satisfaction of women entrepreneurs of GunturDistrict.

\section{Methodology of the Study:-}

The scope of the study was confined to Guntur District. The main source of primary data was collected from women Entrepreneurs through a well-structured questionnaire, Personalinterview;consequently some of them were through Secondary data. The researcher has proposed the sampling techniques for the selection of the respondents. A sample size of 90 respondents was selected.

\section{Statistical Techniques:-}

All these data are to be arranged in various forms of table's. In order to analyze the socio-economic factors by using Chi-Square Test consequently statistical tools applied.

\section{Data Analysis and Interpretation:-}

This study has aimed the problems and prospects of women entrepreneurs in Guntur districts. For this purpose the study conducted for 90 respondents of the women entrepreneurs. An attempt has been made in this section to analyze the collected data with reference to the activities of the women entrepreneurs a detailed analysis is given below. The table 2 shows that problems faced by women entrepreneurs, by usingRank order.

Table 1:- Socio-Economic Factors of Respondents.

\begin{tabular}{|l|l|l|l|}
\hline Personal Characteristics & Category & $\begin{array}{l}\text { No. of } \\
\text { Respondents }\end{array}$ & $\begin{array}{l}\text { Percentage } \\
\%\end{array}$ \\
\hline Age & Below 30 Years & 17 & 18.88 \\
\hline & $30-40 \quad$ Years & 35 & 38.88 \\
\hline & $40-45 \quad$ Years & 28 & 31.11 \\
\hline & 50 above & 10 & 11.13 \\
\hline & Total & $\mathbf{9 0}$ & $\mathbf{1 0 0}$ \\
\hline Marital Status & Married & 61 & 67.77 \\
\hline & Single & 39 & 43.33 \\
\hline & Total & $\mathbf{9 0}$ & $\mathbf{1 0 0}$ \\
\hline
\end{tabular}




\begin{tabular}{|c|c|c|c|}
\hline \multirow[t]{6}{*}{ Educational Status } & Illiterate & 5 & 5.56 \\
\hline & BELOW H.S.C & 11 & 12.23 \\
\hline & H.S.C & 16 & 17.78 \\
\hline & Intermediate Level & 40 & 44.45 \\
\hline & Graduate Level & 18 & 20 \\
\hline & Total & 90 & 100 \\
\hline \multirow[t]{6}{*}{ Monthly Income } & Less than 10,000 & 13 & 14.45 \\
\hline & $10,000-20,000$ & 34 & 37.78 \\
\hline & $20,000-30,000$ & 23 & 25.56 \\
\hline & $30,000-40,000$ & 12 & 13.33 \\
\hline & Above 40,000 & 8 & 8.89 \\
\hline & Total & 90 & 100 \\
\hline \multirow[t]{5}{*}{ Entrepreneur Experience (In Years) } & $0-5$ & 37 & 41.11 \\
\hline & $6-10$ & 29 & 32.22 \\
\hline & $10-15$ & 18 & 20.07 \\
\hline & $16-20$ & 6 & 6.6 \\
\hline & Total & 90 & 100 \\
\hline \multirow[t]{5}{*}{ Size of the Business } & Below 1 Lakh & 42 & 46.67 \\
\hline & 1-5 lakh & 22 & 24.44 \\
\hline & 5-10 Lakh & 17 & 18.89 \\
\hline & Above 10 Lakh & 9 & 10 \\
\hline & Total & 90 & 100 \\
\hline \multirow[t]{5}{*}{ Source of Capital } & Husband Income & 32 & 35.56 \\
\hline & Personal Savings & 27 & 30 \\
\hline & Loans from Banks & 23 & 25.56 \\
\hline & $\begin{array}{l}\text { Loans from Financial Institutions and } \\
\text { others }\end{array}$ & 8 & 8.89 \\
\hline & Total & 90 & 100 \\
\hline \multirow[t]{6}{*}{ Line of Business Activity } & Manufacturing & 38 & 42.22 \\
\hline & Trading & 24 & 26.67 \\
\hline & Services & 16 & 17.78 \\
\hline & Retail & 10 & 11.11 \\
\hline & Others & 2 & 2.22 \\
\hline & Total & 90 & 100 \\
\hline
\end{tabular}

Source: Primary Data Collected from Respondents

Table 2:-Problems of Women Entrepreneurs in Guntur District Using Rank Order Analysis:

\begin{tabular}{|l|l|l|}
\hline Factors & Mean Score & Rank \\
\hline Lack of Family Support & 5.29 & 1 \\
\hline Poor Credit Facilities & 5.20 & 2 \\
\hline Financial Deficit & 5.11 & 3 \\
\hline Lack of Proper training & 4.82 & 4 \\
\hline No Proper Planning & 4.71 & 5 \\
\hline Lack of experience & 4.32 & 6 \\
\hline Male Dominant & 4.16 & 7 \\
\hline Lack of Govt Support and Subsidies & 3.59 & 8 \\
\hline High Rates of interest & 3.29 & 9 \\
\hline Non- repayment of loan by the members & 3.01 & 10 \\
\hline Difficulty in Finding suitable Market & 2.92 & 11 \\
\hline Health Problems & 2.16 & 12 \\
\hline Other Problems & 1.92 & 13 \\
\hline
\end{tabular}


The findings presented in table 2 as it evoke the rank order of sub factors instituting above cited domains. All sub factors are arranged from highest to lowest on the basis of their respective means. Among the these factors, the $1^{\text {st }}$ rank focuses on family support and the $2^{\text {nd }}$ rank focuses on poor credit facilities and these are the important factors for women entrepreneurs. The 3rd and 4th ranks identify the difficulties that women face related to Finance \& Economic issues. The table gives a clear picture of most to least affecting factors.

Table 3:- Chi-Square Test for the Opinion of women Entrepreneurs:

\begin{tabular}{|l|l|l|l|l|l|}
\hline SI.NO & Factors & $\begin{array}{l}\text { Chi- } \\
\text { Square } \\
\text { Value }\end{array}$ & $\begin{array}{l}\text { Degree of } \\
\text { Freedom }\end{array}$ & Table Value & Result \\
\hline 1 & Age & 17.28 & 6 & 16.90 & Significant** \\
\hline 2 & Marital Status & 12.52 & 2 & 5.96 & Significant** \\
\hline 3 & Education qualifications & 14.95 & 4 & 13.26 & Significant** \\
\hline 4 & Income & 3.69 & 6 & 12.57 & Not Significant \\
\hline 5. & Size of the Business & 7.19 & 4 & 9.53 & Not Significant \\
\hline 6 & Source of Capital & 13.73 & 6 & 12.59 & Significant* \\
\hline 7 & Line of Business Activity & 11.59 & 4 & 9.49 & Significant $*$ \\
\hline 8 & & & & & Not Significant \\
\hline
\end{tabular}

Note: Significant * at 5\% Level, Significant ** at $1 \%$ Level

Source Primary Data

\section{Chi-Square Analysis:-}

The socio-Economic factors and opinion of the respondents is applied for the Chi square Test. Table 3 reveals that the factors are Age and education are significant at $1 \%$ level. Marital status, Line of Business Activity, Source of capital are significant at 5\% level. The remaining factors are not significant at $5 \%$ level.

\section{Findings:-}

1. $38.88 \%$ of the respondents are belonging to $30-40$ years age group of the entrepreneurs. $31.11 \%$ of the respondents are between the ages of $40-50$ year. The $18.88 \%$ of the respondents are below the 30 years age group and $11.13 \%$ of respondents are above 50 years.

2. $44.45 \%$ of the respondents are belonging to Intermediate Education Level of the entrepreneurs. $20 \%$ of the respondents are graduates and $17.78 \%$ of the respondents are H.S.C. The $5.56 \%$ and $12.23 \%$ of the respondents are Under HSC level and illiterates.

3. $37.78 \%$ of the respondents are belonging to 10,000 to 20,000 incomes of families. $25.56 \%$ of the respondents are 20,000 to 30,000 income group, $14.49 \%$ of respondents are Below 10,000 and $8.89 \%$ of the respondents are above 40,000 .

4. $42.22 \%$ of the respondents are dealing with manufacturing types of business. $26.67 \%$ of the respondents who are engaged in trading type of business. Only $16 \%$ of the respondents are doing our business for service sectors. $10 \%$ of the respondents are combined all types of business.

5. $61 \%$ of the respondents are married category and $31 \%$ of the respondents are unmarried. Therefore, marital status is an important factor to determine the women entrepreneurs.

6. $46.67 \%$ of the respondents are invested below 1 Lakhs in their business. $24.44 \%$ of the respondents are 1 lakhs to 5 lakhs category.

7. $35 \%$ of the finance sources from Husband's income, $30 \%$ of the respondents financed from personnel savings and $25.56 \%$ are loaned from banks as well as $8 \%$ respondent's financial sources are other sources.

8. $41.11 \%$ of the respondent's opinion is Entrepreneur Experience 0 to 5 years, 32.22\% of the respondent's opinions are 6 to 10 years, and $20.07 \%$ of the respondent's opinions are $10-15 \%$.

\section{Suggestions:-}

1. Most of the women entrepreneurs are of the opinion that because ofFamily Support and also

2. Financial Problems

3. Finance is the first major problem for women entrepreneurs. Hence, the government should provide loan facility which should be interest free to encourage women entrepreneurs. To attract more women entrepreneurs, they should give subsidies. 
4. They don't have Technical Knowledge and they are not able to survive in the market. Hence, the government should conduct frequent training programmes with regard to adopting new technology; this training should be made compulsory for women entrepreneurs.

5. Parents of women entrepreneurs should be encouraged in spending money on setting up a business rather than giving preference to their marriage.

6. Marketing is one of the main problems for women entrepreneurs. They will help them in selling their products at a reasonable price.

7. There are no proper infrastructure facilities and proper location for the development of women entrepreneurship. Hence, separate training institutes may be set up exclusively for women entrepreneurs to reduce the initial investment and to create a special environment.

\section{Conclusion:-}

The study tells us that women are ready to face the challenges associated with setting up of business. Women education is contributing to a great extent to the social transformation. The future will see more women venturing into areas traditionally dominated by men. The socio background factors, type and mode of business, finance, familyand training programmes are the important problems of women entrepreneurs in Guntur District, Andhra Pradesh.

\section{References:-}

1. Ram Naresh Thakur (2009). "Rural Women Empowerment in India" in Empowerment of Rural Women in India Kanishka Publishers, New Delhi.

2. Bhatia Anju (2000) "Women Development and NGOs". Rawat Publication, New Delhi.

3. Singh, S., Simpson, R., Mordi, C. and Okrfore, C., (2011). 'Motivation to become an entrepreneur: A study of Nigerian women's decision', African journal of economic and management sciences, Vol. 2, No. 2, pp. 202-219.

4. Tambunan, T., (2009). 'Women entrepreneurs in Asian developing countries their development and main constraints', Journal of Development and Agricultural Economics, Vol. 1, No. 2, May, pp. 27-40.

5. https://yourstory.com/2016/04/kstart-women-entrepreneurship-survey/

6. Amutha, D., (2011). 'Enterprise Involvement of Women Entrepreneurs', Research on Humanities and Social Sciences, Vol. 1, No. 1, pp. 39-44.

7. Neergaard, H. and Thrance, C., (2011). 'The Nordic Welfare Model: Barrier of facilitator of women's entrepreneurship in Denmark?' International Journal of Gender and Entrepreneurship, Vol. 3, No. 2, pp. 88-104. Palaniappan, G., Ramanigopal, C.S. and Mani, A., (2012).

8. Rao, S.T., Rao, G.T. and SuriGanesh, M.P., (2011). 'Women Entrepreneurship in India (A case study in Andhra Pradesh)', The Journal of Commerce, Vol. 3, No. 3.

9. Ahl, H., (2006). 'Why research on women entrepreneurs needs new directions', Entrepreneurship Theory and Practice, Vol. 30, No. 5, August, pp. 596-621

10. Pareek, (1992). 'Entrepreneurial role stress.' Mimeographed Ahmedabad: Indian Institute of Management.

11. Lalita .N, (2005) "Micro Finance and Rural Development", Gandhi gram Rural Institute, Gandhi gram, Dindigal, Tamilnadu. 